\title{
First record of Pagellus bellottii (Teleostei: Sparidae) in the Bay of Biscay, France
}

Samuel P. Iglésias ${ }^{*}$ and Pascal Lorance ${ }^{2}$

\begin{abstract}
The red pandora, Pagellus bellottii, is a tropical and subtropical demersal porgy (Sparidae) distributed in the eastern Atlantic, mostly along African coast. Several recent records in the Gulf of Cádiz suggests a northward migration of the species.

Two specimens of the red pandora were caught in the southeast Bay of Biscay during the 2014 French fishery survey programme. They represent the first records of the species for the Bay of Biscay and for French waters. In Europe the species has been previously recorded only in the Gulf of Cádiz in the Atlantic and in Spanish Mediterranean waters. The hypothesis that global climate change is a factor for this almost $7^{\circ}$ northward species range extension, commonly distributed in the tropical and subtropical eastern Atlantic along the African coast, is analysed using temperature data from the World Ocean Atlas 2013.

The northern extension of the distribution range of Pagellus bellottii most probably is a consequence of the warming waters of the Bay of Biscay over the past decades.
\end{abstract}

Keywords: Red pandora, Porgies, Range extension, Immigrant, Tropicalisation, Northeast Atlantic

\section{Background}

The red pandora, Pagellus bellottii Steindachner, 1882, is a tropical and subtropical demersal Sparidae (Porgies) that lives over hard or sandy bottoms in coastal marine waters. It mostly occurs at depths ranging from 10 to 50 metres. It is distributed in the eastern Atlantic, from the Strait of Gibraltar to Angola and the Canary Islands where it is occasionally recorded (Bauchot and Hureau, 1986; Franqueville, 1983). The species is also recorded in the southwestern Mediterranean, in the Alboran Sea, off the Algerian coasts and in the Gulf of Gabes (Oral, 2010). The records of the species in the eastern Mediterranean, Syrian and Israeli waters (Fricke, et al. 2014, Fig. 1) is questioned. We consider these records are misidentification of Pagrus pagrus (Linnaeus, 1758). Pagellus bellottii was also included in the checklist of the fishes from Portugal as a consequence of records coming from the Algarve region, about $36^{\circ} 59^{\prime} \mathrm{N}, 8^{\circ} \mathrm{W}$, the northernmost records in Atlantic waters (de Castro, 1967; Erzini et al., 1996; Carneiro et al., 2014; Carneiro

\footnotetext{
*Correspondence: iglesias@mnhn.fr

'Muséum national d'Histoire naturelle, UMR BOREA 7208, Station de Biologie Marine de Concarneau, Place de la Croix, 29900 Concarneau, France Full list of author information is available at the end of the article
}

com. pers.). Some specimens were also recorded in Spanish Mediterranean waters, in the Bay of Almería about $36^{\circ}$ $47^{\prime} \mathrm{N}, 2^{\circ} 25^{\prime} \mathrm{W}$ (Lucena, et al. 1982), the northernmost records for the Mediterranean waters. Herein, the first record of P. bellottii in the Bay of Biscay is reported.

\section{Results}

\section{SYSTEMATICS}

Order PERCIFORMES

Family SPARIDAE Rafinesque, 1810

Genus Pagellus Valenciennes, 1830

Pagellus bellottii Steindachner, 1882

(Figure 1)

The two specimens were similar in size, with a total length (TL) of 265 and $274 \mathrm{~mm}$ respectively (Fig. 1). Morphometrics, weights and meristic counts are presented in Table 1. Diagnostic characters of the two specimens included occipital scales extending forward to the anterior margin of eye; molar teeth in two series; anal fin with 10 rays; bright silvery pale red colours; dark red mark at the origin of the lateral line and the upper margin of opercle; fins yellow-pinkish; inside of mouth whitish; and longitudinal yellow and grey stripes along body. 


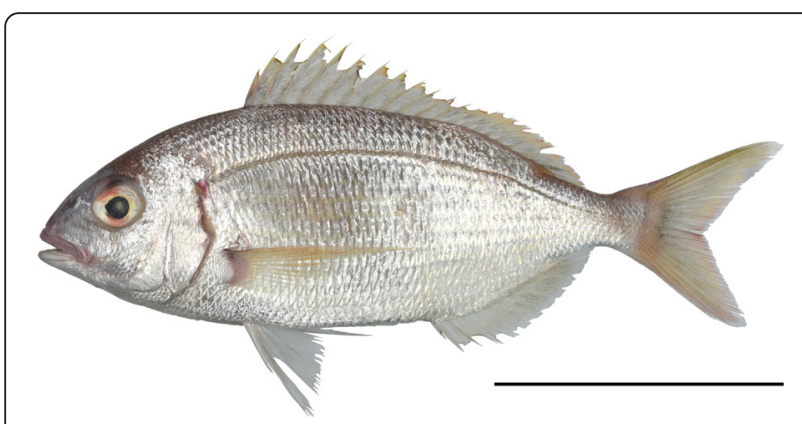

Fig. 1 Pagellus bellottii Steindachner, 1882, voucher MNHN-IC 2015-0144, 265 mm TL, 26 Oct. 2014, southern Bay of Biscay, France. Scale bar $=10 \mathrm{~cm}$

The average seasonal water temperature cycle at the depth of $20 \mathrm{~m}$ in the southeast Bay of Biscay in 20052012 was overall cooler than those of the corresponding seasons to the south of Angola in 1955-1964, although the annual cycles of the two areas overlap (Fig. 2). Recent winter temperatures in the Bay of Biscay have been cooler by more than $2{ }^{\circ} \mathrm{C}$ than winter temperatures to the south of Angola in 1955-1964, while summer temperatures are comparable. Winter temperatures in the Bay of Biscay are almost $5{ }^{\circ} \mathrm{C}$ cooler than in the Gulf of Cádiz.

\section{Discussion}

The two current records are the northernmost occurrences ever reported for the species, and the first record in the Bay of Biscay and French waters. These new records represent a significant range extension for the species of about $6^{\circ} 45^{\prime}$ to the north. The specimens were collected together with congeners of the species Pagellus erythrinus (Linnaeus, 1758). Four species of Pagellus are now known to be present in French waters: P. acarne (Risso, 1827), P. bogaraveo (Brünnich, 1768), P. erythrinus and the newly recorded $P$. bellottii.

Table 1 Morphometrics (mm), weight (g) and meristic counts of the two specimens of Pagellus bellottii from the Bay of Biscay

\begin{tabular}{lll}
\hline Collection no. & MNHN-IC 2015-0144 & MNHN-IC 2015-0145 \\
\hline Total length & 265 & 274 \\
Fork length & 231 & 240 \\
Standard length & 205 & 210 \\
Head length & 60 & 61 \\
Total weight & 266.5 & 305.5 \\
Scales on lateral line & 55 & 58 \\
Dorsal fin & $\mathrm{XII+10}$ & $\mathrm{XII+10}$ \\
Pectoral fins & 15 & 16 \\
Pelvic fins & $\mathrm{I}+5$ & $\mathrm{I}+5$ \\
Anal fin & $\mathrm{III+10}$ & $\mathrm{III+10}$ \\
Gillrakers on 1st arch & $6+1+9$ & $6+1+9$ \\
\hline
\end{tabular}

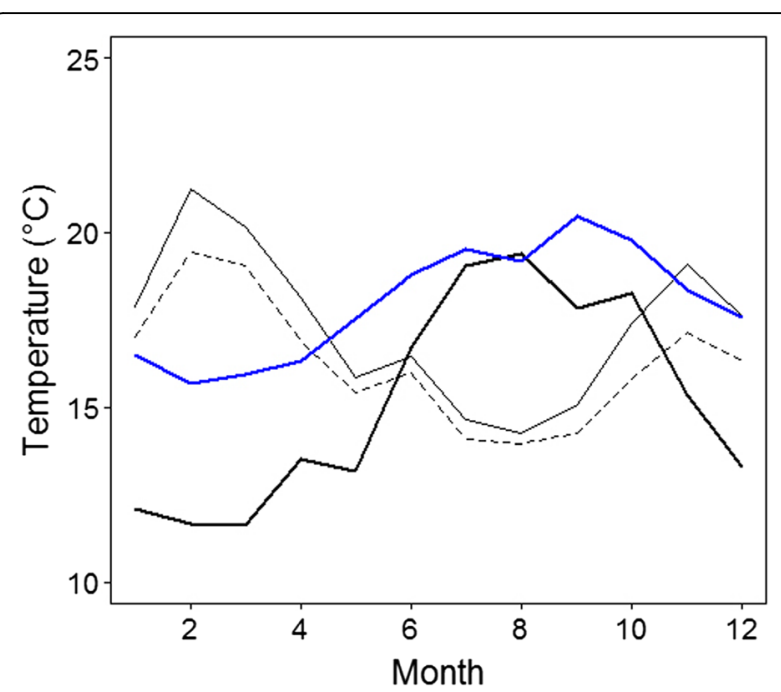

Fig. 2 Comparison of the average seasonal temperature cycle in the South eastern Bay of Biscay in 2005-2012 (thick black line) to that from 1955-1964 in the Gulf of Cádiz (blue line) and to the South of Angola by $16-17{ }^{\circ} \mathrm{S}$ (thin continued line) and by $17-18^{\circ} \mathrm{S}$ (dotted line). Sea temperatures from the World Ocean Atlas 2013 (Boyer et al. 2013)

Several sparids have displayed a significant northward range extension in European Atlantic marine waters over the last few decades. The phenomenon was observed for Diplodus cervinus (Lowe, 1838), D. vulgaris (Geoffroy Saint-Hilaire, 1817), D. sargus (Linnaeus, 1758), and Pagrus auriga Cuvier, 1816 (Quéro et al., 2004; Bañón et al., 2014; pers. obs.). The population abundance of uncommon native sparid species in the Bay of Biscay, such as Sparus aurata Linnaeus, 1758, Dentex dentex (Linnaeus, 1758), and Boops boops Linnaeus 1758 (Quéro et al., 2009; pers. obs.), appears to have increased over the last few decades. The observed northward range extension of a number of slope and shelf species in the Bay of Biscay was shown to coincide with the warming of both the Atlantic waters of the poleward Slope Current, and that of shelf waters in the southern Bay of Biscay (Quéro et al., 1998). The warming of the Bay of Biscay over 40 years, from the mid-1960s to the mid-2000s, was shown to be roughly twice as fast as that of the overall North Atlantic basin (Michel et al., 2009), which could be seen as a factor in favour of the extension of a mostly tropical species such as $P$. bellottii. Nevertheless, even in the warmer southeast Bay of Biscay temperatures remain far cooler than in the tropical coastal waters of West Africa where the species is most abundant. In summer and only in surface layers, recent water temperatures in the Bay of Biscay are similar to or warmer than temperatures in the 1950s-1960s in the Strait of Gibraltar and South Angola, corresponding to extreme latitudes of the native range. In contrast, winter temperatures in the southeast Bay of Biscay are much cooler than in all other areas of the species native range and recent occurrence. 
The status of the two individuals at hand is unknown. They may be either vagrant members of their population, as was recently observed for a cod Gadus morhua individual fished in the Mediterranean Sea (Morey et al., 2012), members of a small recently established resident population or seasonal migrants. In any case, whether larvae were carried or juveniles/adults actively migrated to the catching location is unknown. It seems unlikely that these two individuals were spawned in the Gulf of Cádiz, from which they would have had to have been carried/travelled more than $1300 \mathrm{~km}$. The recent occurrences in the Gulf of Cádiz of both juveniles from $6 \mathrm{~cm}$ $\mathrm{TL}$ and mature individuals up to $30 \mathrm{~cm}$ TL may reflect the existence of a breeding population in this area (Torres et al., 2012; Carneiro et al., 2014). Furthermore, previous occurrences may have passed unnoticed in commercial catches and even in fishery science surveys, because of the strong similarity to other Pagellus species, and in particular to P. erythrinus. It is worth noting that it is only because two individuals of each species were caught in the same haul in 2014, that this first record was made. If individuals of $P$. bellottii were previously caught without $P$. erythrinus in the same haul, they may have been misidentified as the latter. Therefore, the confirmation of the status of the species from Portugal to the Bay of Biscay requires careful monitoring of Pagellus spp. catches in all sampling opportunities from the Gulf of Cádiz to the Bay of Biscay in forthcoming years.

\section{Conclusions}

The northern extension of the distribution range of the tropical-subtropical Sparidae Pagellus bellottii most probably is a consequence of the warming waters of the Bay of Biscay over the past decades.

\section{Methods}

On the $26^{\text {th }}$ October 2014, two specimens of Pagellus bellottii were collected by the French research vessel Thalassa during the fishery science survey Evhoe 2014 at the station S-0853 (Fig. 3). They were collected by bottom trawl in the southeast of the Bay of Biscay, near the French coast, off Vieux-Boucau-les-Bains at $43^{\circ} 46.9^{\prime}-43^{\circ}$ $48.9^{\prime} \mathrm{N}, 1^{\circ} 27.2^{\prime}-1^{\circ} 26.6^{\prime} \mathrm{W}$ at $25.1-25.6 \mathrm{~m}$ depth. Species identification was made according to Bauchot and Hureau (1986). Fresh specimens were photographed in a standard manner then a tissue sample was taken from the specimens and recorded under collection numbers (BPS-3069 and 3070) for future genetic analyses. The specimens were fixed in $4 \%$ formalin for some weeks then preserved in $70 \%$ ethanol and deposited in the Ichthyologic Collection of the Muséum national d'Histoire naturelle of Paris (MNHN-IC 2015-0144 and 2015-0145).

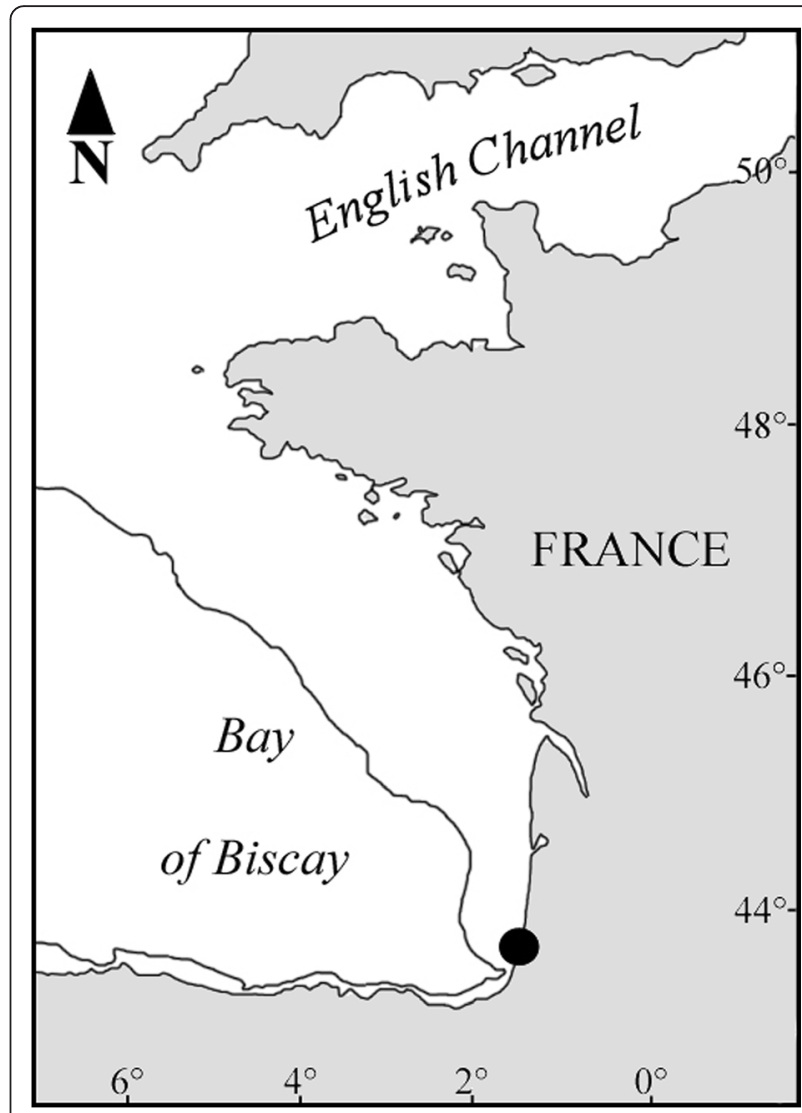

Fig. 3 Location (black dot) of the catch of two specimens of Pagellus bellottii off Vieux-Boucau-les-Bains, southern Bay of Biscay, France, on 26 Oct. 2014

\section{Competing interests}

The authors declare that they have no competing interests.

\section{Authors' contributions}

SPI did the taxonomic analyses of the specimens. PL collected the specimens and did the analyses of the water seasonal temperature cycle. The two authors drafted the manuscript. Both authors read and approved the final manuscript.

\section{Authors' information}

$\mathrm{SPI}(\mathrm{PhD})$ is associate professor at MNHN. He performs research in ichthyology, systematics, ecology and fisheries. PL (PhD) is researcher at IFREMER in the unit of ecology and models for fisheries science. He performs research on fish populations, fisheries and ecosystem approach to management.

\section{Acknowledgements}

The authors are grateful to M. Carneiro for personal communication and to A. Curd for English language review. The EVHOE survey is co-funded by IFREMER and the European Union through the Data collection Framework (DCF).

\section{Author details}

${ }^{1}$ Muséum national d'Histoire naturelle, UMR BOREA 7208, Station de Biologie Marine de Concarneau, Place de la Croix, 29900 Concarneau, France.

IFREMER, rue de I'lle d'Yeu, BP 21105, 44311 Nantes, cedex 03, France.

Received: 29 January 2016 Accepted: 8 February 2016

Published online: 10 March 2016

\section{References}

Bañón R, Barros-García D, Mucientes G, De Carlos A. Northernmost records of Pagrus auriga (actinopterygii: perciformes: sparidae) and Pomadasys incisus (Actinopterygii: 
Perciformes: Haemulidae) in the eastern Atlantic. Acta Ichthyologica et Piscatoria. 2014:44:323-7. http://dx.doi.org/10.3750/AlP2014.44.4.07.

Bauchot M-L, Hureau J-C. Sparidae. In: Whitehead PJP, Bauchot M-L, Hureau J-C, Nielsen J, Tortonese E, editors. Fishes of the north-eastern Atlantic and the Mediterranean, vol. 2. Paris: UNESCO; 1986. p. 883-907.

Boyer TP, Antonov Jl, Baranova OK, Coleman C, Garcia HE, Grodsky A, Johnson DR, Locarnini RA, Mishonov AV, O'Brien TD, Paver CR, Reagan JR, Seidov D, Smolyar IV, Zweng MM. World Ocean Database 2013, NOAA Atlas NESDIS 72, S. Levitus (ed.), A. Mishonov (technical ed.). Silver Spring: 2013; p 209. doi:http://doi.org/ 10.7289/N5NZ85MT. Accessed January 2016.

Brünnich MT. Ichthyologia Massiliensis, sistens piscium descriptiones eorumque apud incolas nomina. Accedunt Spolia Maris Adriatici. Hafniae et Lipsiae. Ichthyologia Massiliensis, sistens piscium descriptiones eorumque apud incolas nomina; 1768 .

Carneiro M, Martins R, Landi M, Costa FO. Updated checklist of marine fishes (Chordata: Craniata) from Portugal and the proposed extension of the Portuguese continental shelf. Eur J Taxonomy. 2014;73:1-73. http://dx.doi. org/10.5852/ejt.2014.73.

de Castro JMO. Nomenclatura portuguesa do pescado. Gabinete de Estudos das Pescas. 1967;39:234

Erzini K, Gonçalves JMS, Bentes L, Lino PG, Cruz J. Species and size selectivity in a Portuguese multispecies artisanal long-line fishery. ICES J Mar Sci. 1996;53:811-9.

Franqueville C. Biologie et dynamique des populations des daurades (Pagellus bellottii Steindachner, 1882) le long des côtes Sénégambiennes. Marseille II: Thèse de Doctorat d'Etat, Université d'Aix; 1983. p. 276.

Fricke R, Golani D, Sonin R, Appelbaum-Golani B. First record of the Red Pandora pagellus bellottii from Israel, South-Eastern Mediterranean (Teleostei: Sparidae). Mar Biodivers Rec. 2014;7:e130. http://dx.doi.org/10.1017/S1755267214001316.

Geoffroy St. Hilaire E. Poissons du Nil, de la mer Rouge et de la Méditerranée. In: Description de l'Egypte ou recueil des observations et des recherches qui ont été faites en Égypte pendant l'expédition de l'Armée français, publié par les ordres de sa Majesté-L'Empereur Napoléon le Grand. Paris: Imprimerie Impériale; 1817.

Linnaeus C. Systema Naturae, Ed X (Systema naturae per regna tria naturae, secundum classes, ordines, genera, species, cum characteribus, differentiis, synonymis, locis, Stockholm; 1758

Lowe RT. A synopsis of the fishes of Madeira; with the principal synonyms, Portuguese names, and characters of the new genera and species. Transactions of the Zoological Society of London. 1838;2:173-200.

Lucena J, Abad R, García L. Primera cita en el Mediterráneo español de Pagellus coupei Dieuzeide, 1960. Investigacion Pesquera. 1982;46:51-4.

Michel S, Vandermeirsch F, Lorance P. Evolution of upper layer temperature in the Bay of Biscay during the last 40 years. Aquat Living Resour. 2009;22:447-61. http://dx.doi.org/10.1051/alr/2009054.

Morey G, Morales-Nin B, Riera F, Grau A, Geffen AJ, Pérez-Mayol S, Chang M-Y, Grau AM. Atlantic cod Gadus morhua in the Mediterranean: a surprising immigrant. Mar Ecol Prog Ser. 2012;467:277-80. http://dx.doi.org/10.3354/ meps09936.

Oral M. Alien fish species in the Mediterranean - Black Sea Basin. J Black Sea Mediterr Environ. 2010;16:87-132.

Quéro J-C, Du Buit M-H, Vayne J-J. Les observations de poissons tropicaux et le réchauffement des eaux de l'Atlantique européen. Oceanol Acta. 1998:21:345-51.

Quéro J-C, Bellail R, Spitz J, Tardy J, Vayne J-J. Observations ichtyologiques effectuées en 2003. Annales de la Société des Sciences Naturelles de la Charente-Maritime. 2004:9:367-70.

Quéro J-C, Spitz J, Vayne J-J, Auby I, De Casamajor MN, Léauté JP, Marie F, Monhurel L, Quinquis J. Observations ichtyologiques effectuées en 2008. Annales de la Société des Sciences Naturelles de la Charente-Maritime. 2009:9:932-40.

Risso A. Histoire naturelle des principales productions de l'Europe méridionale, et particulièrement de celles des environs de Nice et des Alpes maritimes. Paris \& Strasbourg: Levrault; 1827.

Torres MA, Ramos F, Sobrino I. Length-weight relationships of 76 fish species from the Gulf of Cádiz (SW Spain). Fish Res. 2012;127-128:171-5. http://dx.doi.org/10.1016/j.fishres.2012.02.001.

\section{Submit your next manuscript to BioMed Central and we will help you at every step:}

- We accept pre-submission inquiries

- Our selector tool helps you to find the most relevant journal

- We provide round the clock customer support

- Convenient online submission

- Thorough peer review

- Inclusion in PubMed and all major indexing services

- Maximum visibility for your research

Submit your manuscript at www.biomedcentral.com/submit

) Biomed Central 